\title{
Evaluating the Efficiency and Productivity of Insurance Companies with a Malmquist Index: A Case Study for Portugal
}

\author{
Carlos Pestana Barros, Nazaré Barroso and Maria Rosa Borges \\ Instituto Superior de Economia e Gestão, Technical University of Lisbon, Rua Miguel Lupi, 20, 1249-078 \\ Lisbon, Portugal. E-mail: cbarros@iseg.utl.pt
}

This paper estimates changes in total productivity, breaking this down into technically efficient change and technological change by means of data envelopment analysis applied to a representative sample of insurance companies operating in the Portuguese market. The aim of this procedure is to seek out those best practices that will lead to improved performance in the market. We rank the companies according to their change in total productivity for the period 1995-2001, concluding that some companies experienced productivity growth while others experienced a decrease in productivity. The implications arising from the study are considered in terms of managerial policy.

The Geneva Papers (2005) 30, 244-267. doi:10.1057/palgrave.gpp.2510029

Keywords: Portugal; productivity change; Malmquist index

\section{Introduction}

Efficiency at the level of the enterprise is a major issue in contemporary European economics, due to the ever more intense pressure that competition has exerted on prices since the adoption of the European Union's (EU) Single Market Programme (SMP). It was established in 1992 with the aim of facilitating the free movement of goods and services throughout the Member States. In the insurance industry, this pressure has resulted in a number of consolidation mergers and acquisitions, both internally and across borders, allowing for the entry of multinational insurers into what were formerly national markets. However, all of this strategic activity requires a sound, efficient basis if it is to yield successful results. Efficiency in insurance has been analysed in several studies. ${ }^{1}$

This current research is based on our observation of the various threats confronting the Portuguese insurance sector at the present time. Among these, the growing number of major European and U.S. insurance companies that have entered the Portuguese insurance market as a result of the SMP has led to the above-mentioned competition with national insurers. This reveals the small size of most Portuguese insurance companies, arising from the small size of the national market and the relatively low level of disposable income among Portuguese consumers. This small size precludes any possibility of expansion into the European market, as Portuguese insurers lack the

\footnotetext{
${ }^{1}$ Fecher et al. (1993); Gardner and Grace (1993); Fukuyama (1995); and Cummins and Zi (1998), among others.
} 
economies of scale that exist for larger operators, who can benefit from doing business in several contiguous markets. However, in some but not all cases, the process of mergers and acquisitions has had the effect of increasing the size of insurance companies through their purchase of larger shares of the market. Furthermore, a degree of saturation already exists in this insurance market, implying that a continuing process of consolidation will serve to rationalize competition in the medium to long term, by removing the weaker players from the market. Another threat stems from the role played by the State and the policy that has prevailed in recent years. The State is present in the market in the form of a public insurance company created as a result of the recent acquisition of a private insurance company by a public bank. This policy restricts the growth of local companies. Finally, structural rigidities continue to exist in the labour market, giving rise to the collective-action problem ${ }^{2}$ whereby employees can effectively resist the management's efforts to improve performance. This situation happens when the labour market does not link job tenure to performance, which has long been a costly weakness of the labour market in the Portuguese insurance sector.

The national insurance industry reacts to these threats by attempting to increase the efficient use of inputs. One procedure adopted for improving competitiveness is benchmarking. This results from research carried out into an industry's best practices, based on the idea that the widespread application of these can lead to improved performance throughout the whole industry. ${ }^{3}$

The efficiency of insurance companies is a major theme in contemporary research. ${ }^{4}$ Among the benchmarking techniques, data envelopment analysis (DEA), a nonparametric technique, has been the most commonly used in previous research into insurance. ${ }^{5}$ In this paper, we analyse the comparative efficiency of major Portuguese insurance companies, assessing the sector's efficiency by using a variety of metrics to measure inputs and outputs that combine financial, as well as operational, dimensions. Moreover, we evaluate total productivity with the Malmquist index.

The paper follows the tradition of analysing national markets ${ }^{6}$ and departs from the tradition of analysing multi-country markets. ${ }^{7}$ To the authors' knowledge, this is the first article to examine the relative efficiency of Portuguese insurance companies. From an academic perspective, the particular contribution of this paper lies in its presentation of a broader literature review than those included in previously published papers and its testing of the role played by the single insurance licence, established by the EU in 1994, in the growth of the efficiency of the national market. The paper adopts a two-stage approach: in the first stage, a Malmquist index is estimated and, in the second stage, this index is regressed in relation to economic characteristics. The

\footnotetext{
2 Olson (1971).

${ }^{3}$ Diacon et al. (2002); Cummins and Santomero (1999).

${ }^{4}$ viz. Cummins and Weiss (1993); Cummins et al. (1996); Cummins and Zi (1998); Katrischen and Scordis (1998); Rai (1996).

5 For example in Diacon et al. (2002); Cummins et al. (1999).

${ }^{6}$ Fecher et al. (1993); Gardner and Grace (1993); Fukuyama (1995); Cummins and Zi (1998).

${ }^{7}$ Rai (1996); Cummins et al. (1996); Donni and Fecher (1997); Katrischen and Scordis (1998); Diacon et al. (2002).
} 
Malmquist index has been previously used in insurance by Cummins, Weiss and $\mathrm{Zi}^{8}$ and Mahlberg and Url. ${ }^{9}$

The paper is organized as follows: we describe the contextual setting, considering the Portuguese insurance sector in order to shed some light on the threats mentioned above; we survey the existing literature on the topic, with the aim of highlighting the contribution that the present paper seeks to make; we explain the theoretical framework supporting the model used; we present the data and results; we estimate the determinants of the efficient scores; we discuss the results; we put forward the limitations and possible extensions of the study; and finally, we make our concluding remarks.

\section{Institutional setting}

Portugal became a Member State of the then European Community in 1986. The Portuguese insurance sector had to adapt to this new framework, even though, at that time, the only directives on insurance approved by the European Council were the socalled first and second directives, dated 1973 and 1979, respectively, relating to the coordination of laws, regulations and administrative provisions. Those first directives concerned the removal of restrictions on the establishment of companies in Member States, but the authorization was valid only for national territories.

In 1992, the third directives were approved, and they were to be brought into force no later than 1 July 1994. This was considered to be the birth of the insurance single market.

The latter directives presented a strong challenge to the Portuguese insurance industry. Portuguese enterprises were no longer alone in their national market, since any insurance company authorized in any Member State could cover all of the EU market, with or without its being established in other countries. It is, nonetheless, true that overseas insurers had been operating in Portugal long before the country's accession to the EU. In other words, Portuguese insurance companies now had to compete not only within their national territory but all over the EU. Moreover, whereas they had previously carried out their operations in a strictly regulated market, with close control being exercised over contracts and tariffs, they now had to adjust to different conditions, in which consumer protection was now based on the supervision of financial guarantees: solvency margins, technical provisions and minimum guarantee funds.

In 2002 (according to the latest official statistics available), there were 287 insurance companies authorized to operate in the Portuguese market. Most of them specialized either in life or in non-life insurance, while some continued to be composite companies (i.e. they offered both life and non-life insurance). The number of insurance companies established in Portugal has declined slightly in recent years, as shown in Table 1. On the other hand, it can be observed that the number of companies authorized to operate under a freedom-to-provide-services (FPS) regime has greatly increased since 1995

\footnotetext{
${ }^{8}$ Cummins et al. (1999).

${ }^{9}$ Mahlberg and Url (2003).
} 
Table 1 Insurance companies in Portugal

\begin{tabular}{lrrrrrrrr}
\hline Insurers & 1995 & 1996 & 1997 & 1998 & 1999 & 2000 & 2001 & 2002 \\
\hline PPLC & 46 & 50 & 48 & 48 & 49 & 46 & 47 & 44 \\
Mutual & 2 & 2 & 2 & 2 & 2 & 2 & 2 & 2 \\
$\begin{array}{l}\text { Foreign branches } \\
\quad \text { From EU }\end{array}$ & 44 & 40 & 46 & 44 & 41 & 42 & 35 & 37 \\
$\quad$ Outside EU & 3 & 3 & 3 & 3 & 2 & 2 & 2 & 2 \\
FPS & 7 & 55 & 86 & 116 & 149 & 150 & 180 & 202 \\
Total & 95 & 150 & 185 & 213 & 243 & 242 & 266 & 287 \\
\hline
\end{tabular}

Source: Instituto de Seguros de Portugal (ISP).

PPLC - Portuguese public limited insurance companies, FPS - freedom to provide services.

Table 2 Top five insurance companies in 2002

\begin{tabular}{|c|c|c|c|c|c|}
\hline Group & $\begin{array}{l}\text { Number of } \\
\text { employees }\end{array}$ & $\begin{array}{c}\text { Premiums } \\
\text { (thousands } € \text { ) }\end{array}$ & $\begin{array}{l}\text { Claims incurred, } \\
\text { net of reinsurance } \\
\text { (thousands } €)\end{array}$ & $\begin{array}{l}\text { Net operating } \\
\text { expenses } \\
\text { (thousands } € \text { ) }\end{array}$ & $\begin{array}{l}\text { Market } \\
\text { share }^{a} \\
(\%)\end{array}$ \\
\hline Fidelidade Mundial & 2,878 & $1,740,097$ & $1,081,453$ & 240,912 & 20.86 \\
\hline Ocidental Vida & 105 & $1,055,279$ & 482,729 & 11,721 & 12.65 \\
\hline Tranquilidade Vida & 77 & 697,677 & 377,939 & 28,203 & 8.36 \\
\hline Império Bonança & 1,523 & 641,947 & 582,758 & 173,122 & 7.70 \\
\hline Totta Seguros Vida & 46 & 623,510 & 45,635 & 15,910 & 7.48 \\
\hline
\end{tabular}

Source: Insurance Sector and Pension Funds, Annual Report. ISP, 2002.

${ }^{\mathrm{a}}$ Market share $=$ company premiums/total market premiums.

(implementation of the internal single insurance market). In 2002, only 85 companies were formally established in Portugal, the remaining 202 operating under an FPS regime.

Insurance companies are mostly integrated into insurance groups or financial conglomerates. The first 10 groups represent almost 90 per cent of the Portuguese insurance market (Table 2).

The top five insurance companies control 57 per cent of the market, while the top 10 account for almost 75 per cent (Table 3 ).

Bancassurance is strong in Portugal, as many insurance companies are held by banks. In fact, 77 per cent of life insurance is distributed through this channel. In the case of non-life business, only 11 per cent is sold by banks, with the traditional sales channels, mainly agents, continuing to play the main role. Direct sales represent only 10 per cent of non-life insurance and less than 5 per cent of life insurance.

Insurance premiums have increased considerably in the last decade. In 2002, total insurance premiums represented more than 8 billion euros. Life insurance represents more than 50 per cent of the total premiums in the Portuguese insurance market, followed by "Auto", with 22 per cent. Insurance premiums correspond to 6.38 per cent of the Portuguese GDP. The ratio "premiums/resident population" currently amounts 
The Geneva Papers on Risk and Insurance - Issues and Practice

Table 3 Top five market shares in life and non-life-2002

\begin{tabular}{lclc}
\hline \multicolumn{2}{c}{ Life } & \multicolumn{2}{c}{ Non-life } \\
\hline Company & Market Share $(\%)$ & Company & Market Share $^{\mathrm{b}}(\%)$ \\
\hline Ocidental Vida & 22.9 & Fidelidade Mundial & 22.0 \\
Fidelidade Mundial-Vida & 19.0 & Império Bonança & 12.2 \\
Tranquilidade Vida & 15.2 & AXA-Portugal & 8.2 \\
Totta Seguros Vida & 13.5 & Tranquilidade & 8.2 \\
BPI Vida & 4.6 & Allianz-Portugal & 6.6 \\
\hline
\end{tabular}

Source: Insurance Sector and Pension Funds, Annual Report. ISP, 2002.

${ }^{\mathrm{a}}$ Market share $=$ company premiums/total life market premiums.

${ }^{\mathrm{b}}$ Market share $=$ company premiums/total non-life market premiums.

to 800 euros. The Portuguese insurance market now represents 0.31 per cent of the premiums paid in all OECD countries, as against 0.21 per cent in 1995.

In Portugal, the insurance sector is supervised by the Instituto de Seguros de Portugal (Chartered Institute of Portuguese Insurance), which is the supervisory authority not only for insurance companies but also for pension funds (231 funds, which manage 15,550 million euros' worth of investments) and intermediaries (40,283 registered intermediaries, broken down into 30,644 insurance agents, 9,516 canvassers and 123 brokers).

Today, there are several important new issues confronting insurers: the IAS (International Accounting Standards) and the Solvency II Project will doubtless bring about yet more important changes to the industry in this country.

\section{Literature survey}

Efficiency is a major issue in insurance because it is a component of total productivity. Early studies on insurance efficiency focused on partial aspects of productivity, such as ratio analysis ${ }^{10}$ or used the Tornquist price index, ${ }^{11}$ a technique not currently favoured by contemporary researchers.

Contemporary research in the field of insurance employs frontier models. Two contemporary scientific methods used to analyse efficiency quantitatively are the econometric frontier approach and DEA. Both have their advantages and drawbacks. Unlike the econometric stochastic frontier approach, DEA permits the use of multiple inputs and outputs and does not impose any functional form on the data, nor does it make any distributional assumptions for the inefficiency term. Both methods assume that the production function of the fully efficient decision-making unit is known. In practice, this is not the case, and the efficient isoquant must be estimated from the sample data. Under such conditions, the frontier is relative to the sample considered in the analysis.

\footnotetext{
${ }^{10}$ Letza et al. (2001).

11 Bernstein (1999).
} 
Among the papers using DEA, which are of greater relevance for the present study, we draw attention to Mahlberg and $\mathrm{Url}^{12}$ who analyse the Austrian insurance industry to assess the response to the challenges of the single market with the use of two DEA models. The first one is an input-orientated model with constant returns-toscale (CRS). This model is known as CCR following the name of the authors, Charnes, Cooper and Rhodes. ${ }^{13}$ The second model is a model with variable returns-to-scale (VRS). This model is known in the literature as the BCC model, following the names of the authors, Banker, Charnes and Cooper. ${ }^{14}$ They start with 70 firms in 1992 and finish with 59 firms in 1999. They use four inputs: number of employees, liquid investment, gross technical provision and reinsurance premium; and four outputs: market share, profits, total investment income and premium issued. As a second step, they explain the efficiency scores of individual companies through exogenous variables, which, for the CCR model are exposure, size and diversification. For the BCC model, the exogenous variables are the degree of reinsurance, growth and member group. The third step is to estimate the Malmquist productivity index.

Diacon et al. ${ }^{15}$ evaluate the relative efficiency of 450 European long-term insurance companies between 1996 and 1999 with a two-stage approach. In the first stage, they estimate efficiency scores (pure technical efficiency, scale efficiency and mixed efficiency) with a VRS DEA model. The inputs used are total operating expenses net of reinsurance commissions, taken from the general and long-term technical accounts and the non-technical accounts, total capital (including shareholder capital, reserves, participating rights, special untaxed reserves, minority interests, subordinated debt and long-term funds for future appropriations), total technical reserves and total borrowings from creditors. The outputs used are insurance net earned premiums, less rebates and refunds, long-term insurance net earned premiums, less rebate and refunds, and total investment income.

In the second stage, they estimate a Tobit regression with the three efficiency scores regressed in terms of financial ratios, characteristics of the insurance companies, national dummies and year dummies. The general conclusion is that efficiency scores are U-shaped, with both small and large insurers appearing to have higher efficiency scores. Mutual companies display higher levels of efficiency than stock insurers. The most efficient insurers are those that specialize in particular market sectors. Solvency ratios are associated with a higher level of technical efficiency.

Noulas et al. ${ }^{16}$ analyse a variable number of Greek non-life insurance companies for the years 1991-1996 with DEA analysis. The outputs used are revenue from insurancerelated activities (premium income) and revenue from investment activities. The inputs used are salaries and expenses and payment to insurers. The general conclusion is that the industry is highly inefficient, with notable differences existing between the different companies analysed.

\footnotetext{
${ }^{12}$ Mahlberg and Url, op. cit.

${ }^{13}$ Charnes et al. (1978)

14 Banker et al. (1984)

15 Diacon et al. (2002).

16 Noulas et al. (2001).
} 
Cummins et al. ${ }^{17}$ compare the efficiency of 206 stock and 211 mutual insurance companies in the U.S.A. for the period from 1981 to 1990, using a two-stage approach. In the first stage, they estimate DEA scores to assess production and cost frontiers and Malmquist indices to measure productivity growth over time. They use an extensive number of inputs and outputs. In the second stage, they regress the efficiency scores in terms of ratios and dummy variables. The conclusion is that mutual and proprietary insurance companies are involved in different forms of business: mutual insurance companies are more efficient in their marketing of mutual products, but are less efficient in regard to the proprietary insurance market products. On the other hand, proprietary companies are more technically efficient than mutual companies.

Cummins and $\mathrm{Zi}^{18}$ analyse the efficiency of the U.S. life insurance industry, applying econometric frontier models (half-normal model, exponential model and Gamma model) and DEA models (CRS - constant return-to-scale model, VRS variable return-to-scale model, NIRS - non-increasing returns model and FDH - free disposal hull DEA model). They use six outputs: individual life insurance benefit payments, group life insurance benefit payments, individual annuities benefit payments, group annuities benefit payments, accident and health insurance benefit payments and additions to reserves. They use three inputs: quantity of labour, quantity of financial capital and quantity of material. The input prices used are the price of labour, the price of financial capital and the price of material.

Fukuyama $^{19}$ analyses the efficiency of 25 Japanese insurance companies with a Malmquist index for the period 1988-1993, focusing on ownership structure (mutual and stock insurance companies) and on economic conditions (expansion and recession). The outputs used are insurance reserves and loans. The inputs used are the asset value of the company premises, internal personnel and sales representatives. An analysis is carried out of the correlations between the different efficiency measures associated with the Malmquist index.

Cummins $\mathrm{et} \mathrm{al.} .^{20}$ analyse the efficiency of the Italian insurance industry using twostage procedure. In the first stage, they estimate a Malmquist index. The output used for life insurance is the sum of life insurance benefits, with changes in reserves. For non-life insurance, the outputs are the losses incurred in auto property, auto liability, other property and other liability. An additional output used is invested assets. The inputs used are acquisition labour expenses, administrative labour expenses, fixed capital and equity capital. In the second stage, they regress the efficiency scores in terms of other exogenous variables.

Fecher $\mathrm{et} \mathrm{al.}{ }^{21}$ analyse the French insurance industry for 84 life and 243 non-life companies for the period 1984-1989, using a DEA and a parametric Cobb-Douglas model. The DEA is estimated in three versions, including aggregate gross premiums, gross premiums in three branches (civil liability, fire-property, accident-health) and gross premiums in auto and non-auto branches. In the case of life insurance, the net

\footnotetext{
${ }^{17}$ Cummins et al. (1999).

18 Cummins and Zi (1998).

${ }^{19}$ Fukuyama (1997).

${ }^{20}$ Cummins et al. (1996).

${ }^{21}$ Fecher et al. (1993).
} 
returns on financial investment serve as an additional output, along with gross premiums. The inputs are the wage bill and a composite input consisting of various outlays such as capital consumption, purchase of equipment and supplies. The econometric model is estimated with one output, gross premium, while the same inputs are used as in the DEA model. In a second stage, they explain the efficiency scores using exogenous variables (scale, reinsurance ratio, commission ratio, claims to premiums ratio and output structure).

Cummins and Weiss ${ }^{22}$ estimate a translog cost frontier model with the associated share equations for U.S. multiple-line insurance firms for the period 1980-1988. They use seven outputs: discounted long-tail incurred losses for unregulated and regulated states; discounted short-tail incurred losses for unregulated and regulated states; the sum of loss reserves, loss adjustment expense reserves and unearned premium reserves; the product of loss adjustment expenses per dollar of real losses paid times the output extrapolator; and the deflator of business services. The inputs used are labour volume, labour price, material volume (proxied by the real dollar of intermediate expenses), material price (price index of intermediate expenses), capital volume and capital price (net income/capital).

Gardner and Grace ${ }^{23}$ estimate the X-efficiency of the U.S. life insurance industry with the distribution-free approach of Berger (1993) for 561 firms in the period 19851990. The estimated cost function uses operating costs as an endogenous variable and the outputs are the dollar amounts of ordinary life insurance premiums, group life insurance premiums, ordinary annuity considerations, group annuity considerations, group accident and health premiums and securities investments. The input prices are labour, physical capital and miscellaneous items. As a second step, they tested the relationship between the efficiency of firms and their regulation, organizational form (mutual versus stock insurance companies) and distribution system (whether the firm relied on agency-building systems), with these three indicators being measured by dummy variables. Moreover, they include in the exogenous variables a rent-seeking variable (measured by expenditure on bureaux and associations, legal services and advertising), non-admitted assets measured as write-ins and as a per centage of total assets, and control variables (capital structure, market share and size).

\section{Theoretical framework}

In this paper, we adopt the efficient frontier approach, using the Malmquist productivity index based on DEA.

The Malmquist productivity index allows for changes in productivity to be broken down into changes in technical efficiency and changes in technological efficiency.

To set the scene for our productivity measurement, we adopt the framework presented in Figure 1, which shows two observations of the input $(x)$ and output $(y)$ bundles used by a firm in an industry at time $t$ and $t+1$. The aim is to measure the

\footnotetext{
${ }^{22}$ Cummins and Weiss (1993).

${ }^{23}$ Gardner and Grace (1993).
} 


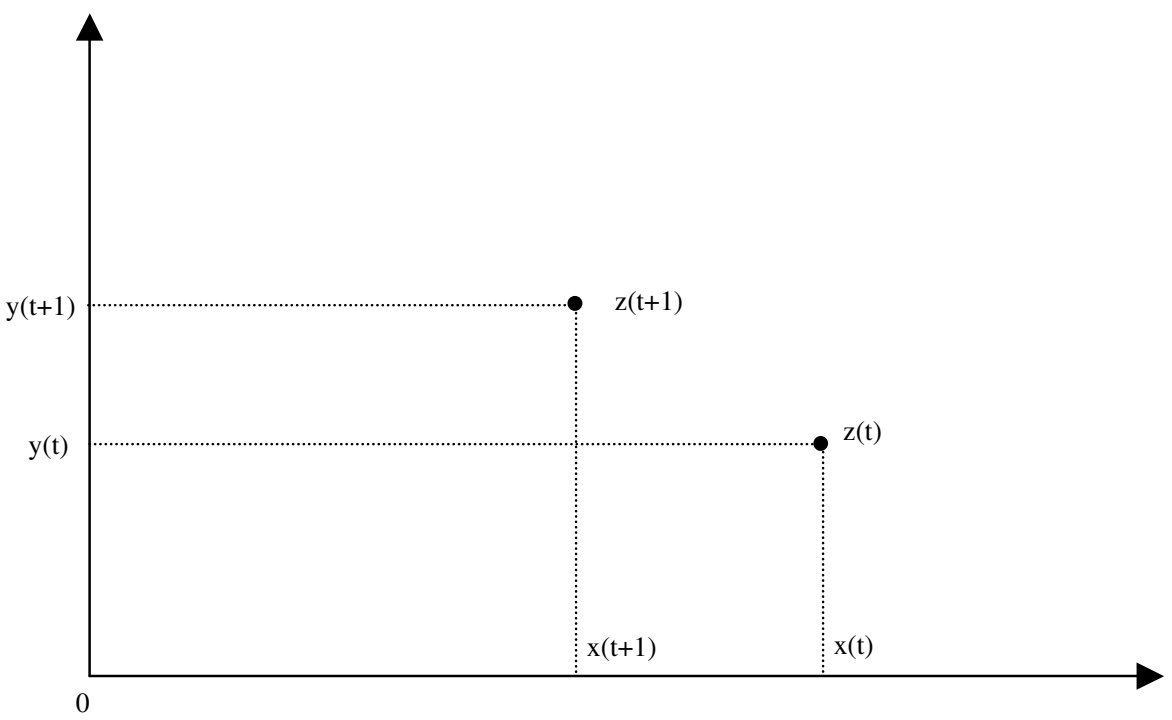

Figure 1. Input-output observations over time.

productivity growth between $t$ and $t+1$ in terms of the change from input-output bundle $z(t)$ to input-output bundle $z(t+1)$.

Productivity is measured through the potential production frontier that is imposed on the production bundle in Figure 2. The production frontier represents the efficient levels of maximum output $(y)$ that can be produced from a given level of input $(x)$. If the firm is technically efficient in period $t$, it produces along the frontier the maximum output attainable, $y(t)$. Point $z(t)=[x(t), y(t)]$ corresponds to a technically inefficient firm, which uses more than the minimal amount of input to produce a given level of output. The input $x(t)$ should be multiplied by the horizontal distance ratio, $O N / O S$, in order to make production of $y(t)$ technically efficient. By analogy, and assuming frontier $t$ as reference, the input $x(t+1)$ should be multiplied by the horizontal distance ratio, $O Q / O R$, in order to achieve technical efficiency in the production of output $y(t+1)$, that is bundle $z(t+1)$. Since the frontier has shifted in the meantime, $z(t+1)$ is technically inefficient in $t+1$. In order for the firm to be efficient in period $t+1$, input $x(t+1)$ must be reduced by the horizontal distance ratio, $O P / O Q$, resulting in bundle $z^{\prime}(t+1)$. Globally, the input ratio inefficiency in $t+1$ is $O P / O R$.

The relative movement of a production observation over time may result from firms catching up with the frontier (technical efficiency change) or may result from the frontier shifting upwards over time (technological efficiency change).

The Malmquist index of productivity growth $(M)$ is the ratio of the input inefficiencies at $t+1$ and $t$.

$$
M=\left[\frac{O P}{O R} / \frac{O N}{O S}\right]=\left[\frac{O Q}{O R} / \frac{O N}{O S}\right] \times \frac{O P}{O Q}=M C \times M F .
$$




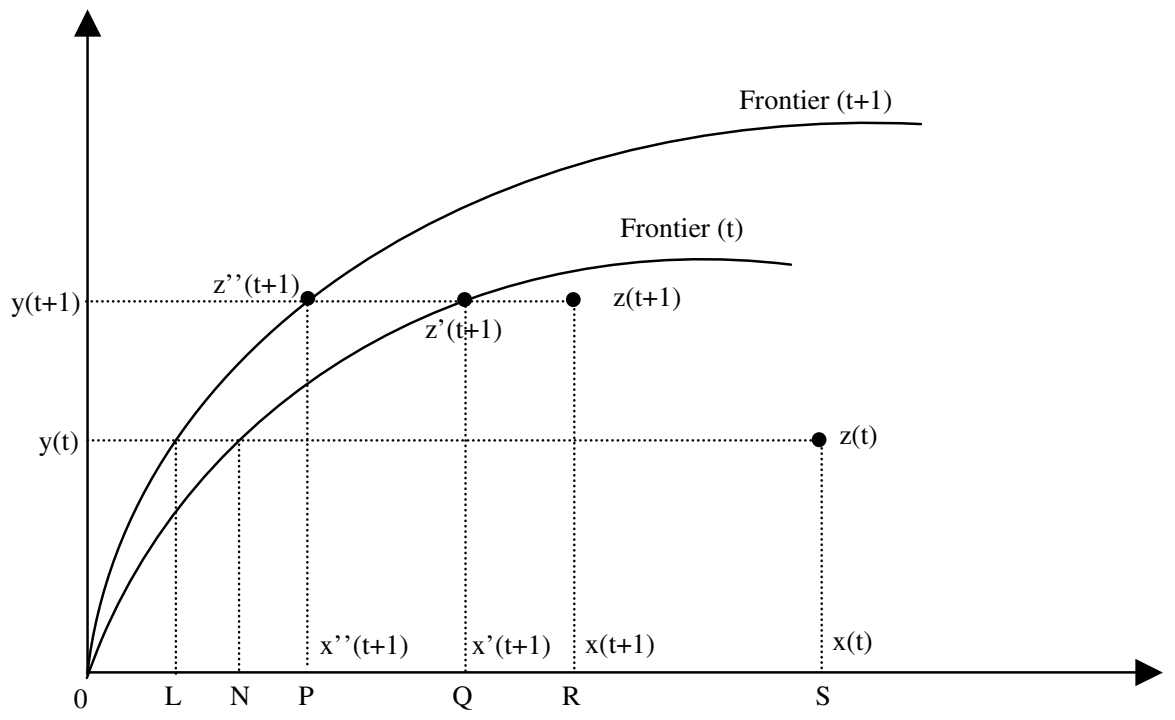

Figure 2. Malmquist index and productivity changes over time.

We can see that the relative efficiency distances of each observation from the original frontier measure the catching-up effect. The frontier shift effect is measured by the relative distance between the frontiers at output level $y(t+1)$, for example, $(O P / O Q)$. This is the benchmark used by Hjalmarsson and Veiderpass ${ }^{24}$ and Price and WeymanJones. ${ }^{25}$ Another benchmark used by Fare et $a l .{ }^{26}$ measures the frontier shift as the relative distance between the frontiers at $t$ and $t+1$, at output level $y(t)$, for example, $(O L / O N)$. An alternative is to determine the shift effect as the geometric mean of these two benchmarks,

$$
[O P / O Q \times O L / O N]^{1 / 2}
$$

Using this last alternative, we have,

$$
M=\left[\frac{O Q}{O R} / \frac{O N}{O S}\right]\left[\frac{O P}{O Q} / \frac{O L}{O N}\right]^{1 / 2}=M C \times M F .
$$

Formally, the Malmquist index is based on the output distance function defined as

$$
d^{T}\left(x^{t}, y^{t}\right) \equiv \inf \left[\theta:\left(x^{t}, \frac{1}{\theta} y^{t}\right) \varepsilon . S^{t}\right],
$$

where $x$ denotes a vector of inputs, $y$ is the vector of outputs, $S$ is the technology set and superscript $T$ denotes the technology reference period, usually $T=t$ or $T=t+1$,

\footnotetext{
${ }^{24}$ Hjalmarsson and Veiderpass (1992).

25 Price and Weyman-Jones (1996).

${ }^{26}$ Fare et al. (1990).
} 
and $1 / \theta$ defines the amount by which outputs in year $t$ could have been increased, given the inputs used, if technology for year $T$ had been fully utilized.

Caves et al. ${ }^{27}$ showed that productivity movements can be measured by a multiinput, multi-output Malmquist index when input and output data are available in physical units, so that no price index problems arise. They argue that the distance function $d(x, y)$ can be used in the construction of the Malmquist index and measure the Malmquist index of change between $t$ and $t+1$ as the ratio

$$
d^{T}\left(x^{t+1}, y^{t+1}\right) / d^{T}\left(x^{t}, y^{t}\right) .
$$

Fare et al. ${ }^{28}$ sought to measure the Malmquist index as the geometric mean of such indices calculated both for year $t$ and year $t+1$ reference technologies as

$$
M\left(x^{t+1}, y^{t+1}, x^{t}, y^{t}\right)=\left[\frac{d^{t}\left(x^{t+1}, y^{t+1}\right)}{d^{t}\left(x^{t}, y^{t}\right)} \cdot \frac{d^{t+1}\left(x^{t+1}, y^{t+1}\right)}{d^{t+1}\left(x^{t}, y^{t}\right)}\right]^{1 / 2} .
$$

Fare et $a .^{29}$ factor this expression into the product of technological change and technical efficiency change as:

$$
\begin{aligned}
& M\left(x^{t+1}, y^{t+1}, x^{t}, y^{t}\right) \\
& =\frac{d^{t+1}\left(x^{t+1}, y^{t+1}\right)}{d^{t}\left(x^{t}, y^{t}\right)}\left[\frac{d^{t}\left(x^{t+1}, y^{t+1}\right)}{d^{t+1}\left(x^{t+1}, y^{t+1}\right)} \frac{d^{t}\left(x^{t}, y^{t}\right)}{d^{t+1}\left(x^{t}, y^{t}\right)}\right]^{1 / 2} .
\end{aligned}
$$

The ratio outside the brackets is the index of change in technical efficiency (i.e. the change in the distance of the observed production from the current maximum feasible production) between years $t$ and $t+1$, while the bracketed term is the index of change in technology (or technological change) between two periods evaluated at $x^{t}$ and $x^{t+1}$.

The Malmquist index is measured either with the distance function or, alternatively, with the reciprocal of the input distance function $\theta(x, y)=[1 / d(x, y)]$. This reciprocal of the input distance function $((x, y)$ is the smallest ratio by which an input bundle can be multiplied and still be capable of achieving a given level of output. The reciprocal distance function is equivalent to the measure of technical efficiency proposed by Farrell $^{30}$ and is the basis of the efficiency distance ratios used in analysing Figure 2.

When the Farrell measurement of technical efficiency (the reciprocal of the input or output distance) is used in constructing the Malmquist index, we obtain productivity growth if $M>1$ and productivity regression if $M<1$.

The Malmquist index ${ }^{31}$ allows for changes in productivity to be broken down into changes in efficiency and technological changes. Unlike the econometric stochastic frontier approach, it offers a different rate of technological change for each individual, which is more appropriate for the purposes of this section, that is, the analysis of technological change by companies. Moreover, since it is estimated with a non-

\footnotetext{
${ }^{27}$ Caves et al. (1982).

${ }^{28}$ Fare et al. (1994).

29 Ibid.

${ }^{30}$ Farrell (1957).

${ }^{31}$ Malmquist (1953).
} 
parametric methodology (DEA), it needs neither to impose any functional form on the data nor to make any distributional assumptions for the inefficiency term.

Additionally, the technical efficiency change can be broken down into pure technical change and scale technical change. The breakdown of the technical efficiency change into its components is based on the VRS hypothesis. ${ }^{32}$ The VRS scores measure pure technical efficiency only, while the CRS index is composed of a non-additive combination of pure technical and scale efficiencies. A ratio of the overall efficiency (CRS) scores to pure technical efficiency scores (VRS) provides us with a measurement of scale efficiency and therefore the estimation of pure technical change. The difference between the CRS scores and the scale efficient change allow us to obtain the pure efficiency change.

$$
\begin{aligned}
M & \left(x^{t+1}, y^{t+1}, x^{t}, y^{t}\right) \\
& =\frac{d_{V R S}^{t+1}\left(x^{t+1}, y^{t+1}\right)}{d_{V R S}^{t}\left(x^{t}, y^{t}\right)}\left[\frac{d_{C R S}^{t+1}\left(x^{t+1}, y^{t+1}\right)}{d_{V R S}^{t+1}\left(x^{t+1}, y^{t+1}\right)} / \frac{d_{C R S}^{t}\left(x^{t}, y^{t}\right)}{d_{V R S}^{t}\left(x^{t}, y^{t}\right)}\right] \\
& \times\left[\frac{d_{C R S}^{t}\left(x^{t+1}, y^{t+1}\right)}{d_{C R S}^{t+1}\left(x^{t+1}, y^{t+1}\right)} \frac{d_{C R S}^{t}\left(x^{t}, y^{t}\right)}{d_{C R S}^{t+1}\left(x^{t}, y^{t}\right)}\right]^{1 / 2} .
\end{aligned}
$$

This efficiency measurement assumes that the production function of the fully efficient firm is known. In practice, this is not the case, and the efficient frontier must be estimated from the sample data. Under such conditions, the frontier is relative to the sample considered in the analysis. We developed a Malmquist productivity estimate from mathematical programming models of the frontier production function. ${ }^{33}$

\section{Data and results}

Frontier models require the identification of inputs (resources) and outputs (transformation of resources). Several criteria can be used in their selection. The first of these, an empirical criterion, is availability. Secondly, the literature survey is a way of ensuring the validity of the research and thus represents another criterion to be taken into account. The last criterion for measurement selection is the professional opinion of relevant individuals. In this paper, we abide by all three of the abovementioned criteria and take into account the overview by Cummins and Weiss. ${ }^{34}$ To estimate the production frontier, we used panel data for the years 1995-2001, obtained from the Instituto de Seguros de Portugal (the Portuguese regulatory authority), on 27 insurance companies ( 7 years $\times 27$ companies $=189$ observations). The insurance companies that are considered in this analysis are listed in Table 5 and were selected on the basis of available data. However, we can see that they represent almost 100 per

\footnotetext{
${ }^{32}$ Fare et al. (1994).

${ }^{33}$ For recent surveys, see Fare et al. (1994); Charnes et al. (1995); Coelli (1996); Coelli et al. (1998); Cooper et al. (2000); and Thanassoulis (2001).

${ }^{34}$ Cummins and Weiss (2002).
} 
The Geneva Papers on Risk and Insurance - Issues and Practice

256

Table 4 Characteristics of inputs and outputs, 1995-2001

\begin{tabular}{lcccc}
\hline Variables & Minimum & maximum & Mean & Stand. dev. \\
\hline Outputs & & & & \\
$\quad$ Claims paid & 0.1 & 640.6 & 99.9 & 134.2 \\
$\quad$ Profits & -208.1 & 1617.2 & 11.5 & 118.7 \\
& & & & \\
Inputs & & & 9.9 & 18.7 \\
$\quad$ Wages & 0.0 & 196.0 & 87.7 & 229.5 \\
$\quad$ Capital & -26.8 & 2023.8 & 46.0 & 149.1 \\
$\quad$ Total investment income & 0.1 & 1927.2 & 178.0 & 244.4 \\
Premiums issued & -0.3 & 1324.7 & & \\
\hline
\end{tabular}

Values in euros $(1997=100)$.

cent of the market, thus being abundantly representative of the Portuguese insurance market.

We respected the DEA convention that the minimum number of DMUs is greater than three times the number of inputs plus output $(189$ observations $>3(2+4)) .{ }^{35}$

We measured insurance production according to a generalized Cobb-Douglas production function. Given the little guidance from the literature review on which variables to use in the analysis we rely on microeconomics ${ }^{36}$ to choose outputs and inputs. Outputs are variables that measure the results of the production such as profits paid to stockholders and claims paid to policyholders. Inputs are labour, capital and other inputs. Therefore, we measured outputs by: claims paid to policyholders and profits paid to the owners; and measured inputs by wages, capital, investment income and premiums. All variables have been deflated to obtain implicit quantities, dividing the value by the GDP deflator obtained from the Portuguese Central Bank Report (Table 4).

We note that the average Portuguese insurance company is characterized as having a high level of heterogeneity.

\section{Results}

The Malmquist index can be calculated in several ways. ${ }^{37}$ In this study, we estimate an output-oriented Malmquist productivity index, based on DEA. Output-oriented efficiency measurements are appropriate if we assume that insurance companies act in a competitive market. ${ }^{38}$ In output-oriented models, such as the one adopted in this paper, DEA seeks to identify technical inefficiency as a proportional decrease in input usage. However, it is possible to measure an input-oriented model of technical inefficiency as a proportional increase in output use. As far as insurance

\footnotetext{
35 Raab and Lichty (2002).

${ }^{36}$ Varian (1987).

${ }^{37}$ Caves et al. (1982).

${ }^{38}$ Khumbhakar (1987); Zellner et al. (1966).
} 
companies are concerned, output orientation seems to be the natural choice, due to their competitive position in the market. However, since the input and output Malmquist indices are equal, ${ }^{39}$ this specification is more of a theoretical issue than a practical one.

DEA allows for the estimation of total productivity change in the form of a Malmquist index. The results are presented in Table 5, with the Malmquist index, denoted as total productivity change, broken down into technical efficient change (the diffusion or catch-up component) and technological efficient change (the innovation or frontier-shift component). Moreover, we break down technical efficient change into pure efficient change and scale-efficient change. The insurance companies are ranked according to the results of column 5 .

In Table 5, we can see that the total productivity change score (the Malmquist index presented in column 5) is one or higher than one only for 20 insurance companies out of 27, showing that a large proportion of the insurance companies experienced gains in total productivity in the period considered. The mean score is 1.113 , which is higher than one, confirming that, for the majority of the insurance companies, total productivity increased in the period. However, there are seven insurance companies with a Malmquist index lower than the mean.

The change in the technical efficiency score (column 1) is defined as the diffusion of best-practice technology in the management of the activity and is attributed to investment planning, technical experience and management and organization in the insurance companies. For the period under analysis, we can see that it is higher than one for 13 of the insurance companies, signifying that there was growth in technical efficiency in the period. However, for a proportion of companies, the change in technical efficiency is lower than one, signifying that there was a recession in technical efficiency in the period.

The breakdown of the score for the change in technical efficiency into pure technical efficiency change (column 3) and scale efficiency change (column 4) shows mixed results, with some insurance companies obtaining simultaneous gains in both areas and others obtaining gains in one, but losses in the other. The improvement in pure technical efficiency, which signifies an improvement in managerial skills, shows that there was investment in organizational factors associated with the management of the insurance companies, such as a better balance between inputs and outputs, best-practice initiatives, more accurate reporting, an improvement in quality and so on. The scale efficiency, which is the consequence of size, decreases in the period for many insurance companies. It is important to note that the mean value of pure technical efficiency change is 0.991 and the mean value of scale efficiency change is 0.989 .

Technological change (column 2) is the consequence of innovation, that is, the adoption of new technologies, by best-practice insurance companies. We can see that this index is higher than one for all companies with the exception of only one company out of 27. This indicates that innovation improved in the period for almost all companies, meaning that there was investment in new technologies (methodologies,

39 Thanassoulis (2001, p. 182). 
Table 5 Average technically efficient change and technological change observed in Portuguese insurance companies: 1995-2001 
procedures and techniques) and in the commensurate skills upgrades related to this. However, for the company showing a downward movement in terms of technological change, this is a primary area of concern.

Overall, we observe four combinations of technical efficiency change and technological change:

(i) In the first group, we find 12 companies in which improvements in technical efficiency co-exist with improvements in technology change. These are the bestperforming insurance companies in the period, with improvements registered in technical efficiency, denoting upgraded organizational factors associated with the use of inputs, outputs and the relationship between inputs and outputs.

(ii) In the second group, we find one insurance company in which improvements in technical efficiency co-exist with deteriorations in technology. This is an insurance company with upgraded organizational factors, but without the innovation inherent in investment in new technology, which would provide leverage for the organizational factors. This insurance company needs to acquire new technology and the necessary commensurate skills upgrades in order to improve its performance.

(iii) In the third group, we find 14 insurance companies, in which improvements in technological efficiency co-exist with deterioration of technical efficiency. These companies need to upgrade their managerial skills and scale to improve their performance.

(iv) In the fourth possibility, in which deteriorating technical efficiency co-exists with deteriorating technology, we find no insurance companies.

Hence, our findings encompass several combinations of efficiency change, signifying that there is room for adjustment in almost all of the above-mentioned insurance companies in order to achieve best-practice procedures in insurance management.

\section{Determinants of insurance efficiency}

In order to examine the hypothesis that insurance company efficiency is determined by the 1994 EU Single Insurers' Licence, we followed the two-step approach, as suggested by Coelli et al., ${ }^{40}$ estimating the Tobit regression shown below. The licence allowed European insurers authorized to operate in an EU Member State to enter any other EU national market, through either a subsidiary or a branch, or else through a direct sale or merger. It is recognized in the DEA literature that the efficiency scores obtained in the first stage are correlated with the explanatory variables used in the second term, and that the second-stage estimates will then be inconsistent and biased. ${ }^{41}$ A bootstrap procedure is needed to overcome this problem. ${ }^{42}$ In order to overcome these problems, the DEA model was selected from balance sheets, but the variables in the Tobit model are independent from these, establishing the separation between efficiency drivers and

\footnotetext{
${ }^{40}$ Coelli et al. (1998).

${ }^{41}$ Simar and Wilson (2000).

42 Simar and Wilson (1999).
} 
The Geneva Papers on Risk and Insurance - Issues and Practice

260

Table 6 Censored tobit model (dependent variable: $\theta$ )

\begin{tabular}{lc}
\hline Variable & Parameters \\
\hline Constant & $1.238(3.139)^{*}$ \\
Foreign & $0.052(4.167)^{*}$ \\
Big & $0.045(3.089)^{*}$ \\
EU & $0.145(2.983)^{*}$ \\
Life & $-0.005(2.783)^{*}$ \\
Sigma & $0.012(4.825)^{*}$ \\
Number of total of observations & 189 \\
Loglikelihood & -95.14 \\
\hline
\end{tabular}

Note: The $t$-ratios followed by * are significant at the $1 \%$ level.

balance sheet variables that characterizes the management practices of insurance firms.

$$
\theta_{i, t}=\beta_{1}+\beta_{2} \text { Foreign }_{i, t}+\beta_{3} \text { big }_{i, t}+\beta_{4} E U_{i, t}+\beta_{5} \text { Life }_{i, t}+\varepsilon_{i, t},
$$

where $\theta$ represents the efficient Malmquist score (TFP score). Foreign is a dummy variable equal to 1 for foreign insurance companies in the sample. The inclusion of this variable is based on the fact that foreign companies constitute almost half of the sample, explaining the widespread presence of these companies in the rankings. big is a dummy variable equal to 1 for the larger insurance companies, aiming to capture the role of dimension in efficiency performance. $E U$ is a dummy variable equal to 1 for companies that entered the market after 1994, the year of the inception of the insurance single market, and is intended to capture the role of increased competitiveness in efficiency. Finally, Life is a dummy variable equal to 1 for companies dealing solely in life insurance and 0 elsewhere, aiming to capture the role of efficiency in life insurance companies. The results are presented in Table 6.

The model appears to fit the data well, with a statistically positive sigma coefficient. A likelihood-ratio test $\left(\chi^{2}=-18.25\right)$ rejects the joint hypothesis that the coefficients of all variables are not significantly different from 0 at the 1 per cent level. ${ }^{43}$

The estimations generally conform to a priori expectations. The efficiency scores are positively related with the Foreign variable, which denotes that foreign ownership contributed positively towards the improvement in the company's efficiency. A rationale for this pattern is that foreign companies are more efficient than national companies.

Moreover, the efficiency scores are positively related with the big variable, signifying that the dimension had a positive effect on efficiency. The efficiency scores are positively related with $E U$, meaning that this variable had a positive effect on efficiency. An explanation for this finding is that increased competition translates into increased efficiency. Therefore, the Single Common Market is improving the efficiency of those companies that are active within it. Finally, the efficiency scores are negatively

\footnotetext{
${ }^{43}$ Greene (2003).
} 
related with the Life variable, signifying that this type of company faces different constraints in the Portuguese market, making them less efficient than non-life insurers.

\section{Discussion}

The present paper analyses changes in total productivity in a representative sample of Portuguese insurance companies between 1995 and 2001, a period of intense instability in the sector, due to the combination of several factors.

We emphasize two implications of our findings for managerial policy. Firstly, the management of the companies with the poorest performances should change their managerial procedures in order to adopt an efficient, enhanced-incentive policy, which would enable these inefficient insurance companies to catch up with the efficient frontier. Secondly, the adjustment must be based on the improvement of technical efficiency, as well as technological change.

Technical efficiency is characterized, in a dynamic way, as efficiency change (diffusion), relating to changes between two successive technical-efficiency frontiers. Technical inefficiency is a consequence of one or more factors, the first of these being the principal-agent relationship. ${ }^{44}$ This relates to the difficulty of controlling those empowered as managers to act on behalf of the shareholders. An alternative reason for such inefficiency is unequal access to information on operational activities, that is, an asymmetrical distribution of information among insurance companies, with some of them enjoying more privileged access to relevant market information than others and thereby attracting more customers. This situation is inherent in the lack of transparency in management. ${ }^{45}$ An alternative reason for such inefficiency is that the overall strategy configuration does not enable inefficient companies to prosper, because they lack adequate organizational arrangements. ${ }^{46}$ Finally, another possible reason is $\mathrm{X}$-inefficiency, ${ }^{47}$ which refers to the factors deriving from incomplete markets. Such markets exist in every sphere, but are particularly prevalent in insurance markets. In this situation, the management may be unable to adopt the correct strategy, since it may not know what it should be.

Other possible reasons for inefficiencies are resource-based strategic factors. These include technological change (innovation), which, in a broad economic sense, is related to investment that would improve the total productivity of a productive unit. This arises from capital accumulation, which determines the adoption of technology by best-practice decision-making units, thereby shifting the efficient frontier. In the insurance industry, technological change means investing in new methods, procedures and techniques with the aim of improving results. The results of such investment only take effect in the long term and are not attributable to current management practices. Examples of such strategic factors are the dimensional factors associated with scale

\footnotetext{
44 Jensen and Meckling (1976).

${ }^{45}$ Williamson (1998).

${ }^{46}$ Williamson (1994).

${ }^{47}$ Liebenstein (1966).
} 
and scope, meaning that the profitability of companies with an inappropriate scale and scope is inevitably restricted.

The general conclusion is that there is room for improvement in the management of those companies that are performing badly.

As far as the determinants of efficiency are concerned, we conclude that the contribution of overseas companies to the efficiency scores is positively and statistically significant. Hence, we infer that the main causes of inefficiency are the conditions prevailing in the market. This result is statistically reinforced by the EU effect, emphasizing the role of EU policy in increasing competition and therefore efficiency in the Portuguese Insurance market. The elimination of the constraints encountered by insurance companies in the market would go some way towards improving general efficiency. Moreover, a better and more effective management and control of human resources is needed to increase dimension through mergers and acquisitions. Finally, we conclude indirectly that there are certain elements intrinsic to the management of enterprises that make some of them more efficient than others. Other explanations have been put forward in the course of this paper. Benchmarks are provided for inefficient companies to catch up with the efficient frontier. External factors, which are beyond their control, affect the health of insurance companies. Therefore, the State should take steps to alter the contextual setting in which the insurers operate, in order to induce increases in efficiency. The privatization of the sole publicly owned company in the sample (Fidelidade) would equally serve this end.

Finally, recent evidence has emerged to confirm the prevailing perception among Portugal-based business managers from overseas that incompetence and inefficiency are rife among their Portuguese counterparts. This evidence comes from an exhaustive survey carried out jointly by Ad-Capita Executive Recruitment and Research and the Cranfield School of Management, U.K. (see report in pdf: "Can Portuguese Managers Compete?" at www.adcapita.com). The study highlights areas that are certainly applicable to the current Portuguese insurance industry, reinforcing our findings and considerations about the causes of existing inefficiencies.

What should the managers of inefficient insurance companies do to improve efficiency? Firstly, they should adopt a benchmark management procedure in order to evaluate their relative position and to adopt appropriate managerial procedures for catching up with the frontier of "best practices". Secondly, they should upgrade the quality of their management practices, responding to the criticisms made by the AdCapita report. Giving greater value to educational achievement among the workforce is an example of what can be done in this field. Thirdly, they should adopt human resources policies that limit the principal-agent relationship, as well as eliminate collective action problems, ${ }^{48}$ in that workers can free-ride on the back of the management's own efforts to improve performance. Finally, they should pursue market-oriented strategies that increase outputs and decrease inputs. Moreover, the regulatory agency has an important role to play in improving the efficiency of insurance companies, enforcing the law which bans people from driving without insurance, publishing data on individual companies in order to introduce greater

\footnotetext{
${ }^{48}$ Olson (1965).
} 
transparency into the market resulting in increased competition and enforcing the rules (technical provisions, reserve ratios) relating to the companies themselves. Moreover, the regulatory authority should abandon complacency in its regulation of insurance companies.

\section{Contributions, limitations and possible extensions of this study}

At this juncture, it is appropriate to consider the contribution of our paper to the economics literature on insurance, as well as its limitations and possible extensions. The key contribution is its application of the Malmquist DEA model to this industry, supported by a theoretical model of economic behaviour. Moreover, we present an extensive literature survey, which serves to clarify our paper's contribution. We also undertake an external benchmark analysis, focusing on Portuguese insurance companies. Finally, we present a regression model, which explains factors that affect the efficiency scores of the insurance companies analysed.

This paper has two sets of limitations: firstly, those relating to the data set, and, secondly, those arising as a result of the DEA method.

As far as the data set is concerned, the homogeneity of the insurance companies used in the analysis is questionable, since we compare companies with different sizes and locations, which may face different restrictions and are not therefore directly comparable. However, we can always claim that the units are not comparable and that therefore a ratio analysis could not be carried out either. Moreover, the data set is short, and so the conclusions are limited. In order for the latter to be more generalized, we would need to have a larger panel data set. Reducing the number of observations in DEA variables increases the likelihood that a given observation will be judged as relatively efficient. ${ }^{49}$

We have also combined life and non-life insurance companies, which can be criticized since they clearly do not face the same restrictions. However, in the Portuguese market, the old companies combine these to insurance activities, which make the separation impossible.

The limitations of the DEA model are as follows: DEA neither imposes any functional form on the data nor makes any distributional assumptions for the inefficiency term or a priori distinctions between the relative importance of any combination of inputs and outputs. These limitations are precisely the most distinctive and appealing characteristics of DEA. This efficiency measurement assumes that the production function of the fully efficient insurance company is known. In practice, this is not the case, and the efficient isoquant must be estimated from the sample data. Under such conditions, the frontier is relative to the sample considered in the analysis. ${ }^{50}$ A less appealing characteristic of DEA is that, without statistical distribution hypotheses, DEA does not allow for random errors in the data, assuming away measurement error and chance as factors affecting outcomes. ${ }^{51}$

\footnotetext{
${ }^{49}$ Banker (1993).

${ }^{50}$ Bessent and Bessent (1980).

${ }^{51}$ Seiford and Thrall (1990).
} 
A variety of extensions can be undertaken in relation to this paper. Firstly, in this analysis, the DEA model allowed for complete weight flexibility. In situations in which some measurements are likely to be more important than others, DEA allows for the restriction of factor weights through linear constraints. These linear constraints represent ranges for relative preferences among factors based on managerial input. Such an analysis allows for the effective incorporation of managerial input into the DEA evaluations. Secondly, the input and output dimensions that are considered are context-specific. More comprehensive input and output measurements need to be taken into consideration, namely ones that do not allow for any discretionary factors, such as environmental, socio-economic and quality inputs and outputs. The influence of nondiscretionary variables, which are excluded from the analysis, amounts to an assumption that these factors are constant across the sample. Thirdly, non-parametric, or alternatively parametric, free disposal hull analysis, can be used to assess the efficiency scores. However, previous research has shown that the DEA scores are inferior in value to econometric scores, even though the same ranking is still preserved. ${ }^{52}$

\section{Conclusion}

In this paper, we have analysed total productivity change in a representative sample of Portuguese insurance companies between 1995 and 2001, a period of intense volatility in the sector, due to the combination of several factors. The analysis is based on a DEA model that allows for the incorporation of multiple inputs and outputs in determining relative efficiencies. Benchmarks are provided for improving the operations of poorly performing insurance companies.

We conclude that a State policy designed to encourage the control of wages and the adoption of disincentives to principal-agent relationships and the collective action problem would yield increased efficiency. Furthermore, increasing the governance and transparency of the companies in question would increase their efficiency. European integration is recognized as contributing positively to the efficiency scores. Regarded as one of the best-performing sectors in the Portuguese economy, insurance companies exhibit improvements in technical efficiency, but the deterioration observed in terms of technological change indicates that they are not using inputs in accordance with their market prices.

The major policy implication of this research is that increased competition resulting from the SMP undoubtedly increases the efficiency of the units operating in the previously protected market. Nevertheless, this policy is not sufficient in itself to induce improvements in technological change. More investigation is needed to address the limitations mentioned.

\section{Acknowledgements}

The financial support provided by the Fundação para a Ciência e Tecnologia/MCT under the FCT/POCTI programme partially funded by FEDER is gratefully appreciated. We also thank an anonymous referee

\footnotetext{
${ }^{52}$ Bauer et al. (1998).
} 
for the constructive and thoughtful comments provided on an earlier draft of the paper. The usual disclaimer applies.

\section{References}

AdCapita and Cranfield University (2003) Can Portuguese Managers Compete?, Mimeo, available at www.adcapita.com.

Banker, R.D. (1993) 'Maximum likelihood, consistency and data envelopment analysis', Management Science 39(10): 1265-1273.

Banker, R.D., Charnes, A. and Cooper, W.W. (1984) 'Some models for Estimating Technical and Scale Inefficiencies in Data Envelopment Analysis', Management Science 30: 1078-1092.

Bauer, P.W., Berger, A.N., Ferrier, G. and Humphrey, D.B. (1998) 'Consistency conditions for regulatory analysis of financial institutions: a comparison of frontier efficiency methods', Journal of Economics and Business 50: 85-114.

Bernstein, J.I. (1999) 'Total factor productivity growth in the Canadian life industry: 1979-1989', Canadian Journal of Economics 32(2): 500-517.

Bessent, A.M. and Bessent, E.W. (1980) 'Determining the Comparative Efficiency of Schools Through Data Envelopment Analysis', Educational Administration Quarterly 16: 57-75.

Caves, D.W., Christensen, L.R. and Diewert, W.E. (1982) 'The Economic Theory of Index Numbers and the Measurement of Input, Output and Productivity', Econometrica 50: 1393-1414.

Charnes, A., Cooper, W.W. and Rhodes, E. (1978) 'Measuring the Efficiency of Decision-Making Units', European Journal of Operations Research 2: 429-444.

Charnes, A., Cooper, W.W., Lewin, A.Y. and Seiford, L.M. (1995) Data Envelopment Analysis: Theory, Methodology and Applications, Boston: Kluwer.

Coelli, T.J. (1996) A guide to DEAP version 2.1: A data envelopment analysis (Computer) Program working paper No. 8/96, Centre for Efficiency and Productivity Analysis. University of New England. Armidale, Australia.

Coelli, T.J., Rao, P. and Battese, G.E. (1998) An Introduction to Efficiency and Productivity Analysis,, Dordrecht: Kluwer Academic Press.

Cooper, W.W., Seiford, L.M. and Tone, K. (2000) Data Envelopment Analysis,, Boston: Kluwer.

Cummins, J.D. and Santomero, A. (1999) Changes in the Life Insurance Industry: Efficiency, Technology and Risk Managemen, Boston: Kluwer Academic Publishers.

Cummins, J.D. and Weiss, M.A. (1993) 'Measuring cost efficiency in the property-liability insurance industry', Journal of Banking and Finance 17: 463-481.

Cummins, J.D. and Weiss, M.A. (2002) 'Analyzing Firm Performance in the Insurance Industry, using Frontier Efficiency Methods', In G. Dionne (ed) Handbook of Insurance Economics, Boston: Kluwer, Chapter 26.

Cummins, J.D. and Zi, H. (1998) 'Comparison of Frontier Efficient Methods: An Application to the US Life Insurance Industry', Journal of Productivity Analysis 10(2): 131-152.

Cummins, J.D., Turchetti, G. and Weiss, M.A. (1996) Productivity and technical efficiency in the Italian insurance industry Working paper 96-10 Wharton School.

Cummins, J.D., Weiss, M.A. and Zi, H. (1999) 'Organizational Form and Efficiency: The Coexistence of Stock and Mutual Property-Liability Insurers', Management Science 45(9): 1254-1269.

Donni, O. and Fecher, F. (1997) 'Efficiency and productivity of the insurance industry in the OECD countries', Geneva Papers on Risk and Insurance 85: 523-536.

Diacon, S.R., Starkey, K. and O'Brien, C.O. (2002) 'Size and efficiency in european long-term insurance companies: An international comparison', Geneva Papers on Risk and Insurance 27: 444-466.

Fare, R.S., Grosskopf, S. and Lovell, C.A.K. (1994) Production Frontiers, Cambridge: Cambridge University Press.

Fare, R., Grosskopf, S., Yaisarwarng, S., Li, S. and Wang, Z. (1990) 'Productivity Growth in Illinois Electric Utilities', Resources and Energy 12: 383-398.

Farrell, M.J. (1957) 'The Measurement of Productive Efficiency', Journal of the Royal Statistical Society, Series A 120(3): 253-290. 
Fecher, F., Kessler, D., Perelman, S. and Pestieu, P. (1993) 'Productive Performance of the French Industry', Journal of Productivity Analysis 4: 77-93.

Fukuyama, H. (1997) 'Investigating productive efficiency and productive changes of Japanese life insurance companies', Pacific-Basin Finance Journal 5(4): 481-509.

Gardner, L.A. and Grace, M.F. (1993) 'X-efficiency in the US life insurance industry', Journal of Banking and Finance 17: 497-410.

Greene, W. (2003) Econometric Analysis (5th edn) Upper Saddle River, N.J: Prentice Hall.

Hjalmarsson, L. and Veiderpass, A. (1992) 'Productivity in Swedish Electricity Retail Distribution', Scandinavian Journal of Economics 94(Suppl): 193-205.

Jensen, M.C. and Meckling, W. (1976) 'Theory of the firm: Managerial behaviour, agency costs and capital structure', Journal of Financial Economics 3: 305-360.

Khumabhakar, S.C. (1987) 'Production frontiers and panel data: An application to US class 1 railroads', Journal of Business and Economic Statistics 5(2): 249-255.

Katrischen, F. and Scordis, N. (1998) 'Economies of scale in services: A study of multinational insurers', Journal of international Business Studies 29(2): 295-324.

Leibenstein, H. (1966) 'Allocative efficiency vs X-efficiency', American Economic Review 56(3): $392-415$.

Letza, S., Hardwick, P. and Kowalski, T. (2001) 'Efficiency in the U.K. Life Insurance Industry: Mutual Firms versus Property Firms', Journal of Financial Services Marketing 6(1): 40-50.

Mahlberg, B. and Url, T. (2003) 'The effects of the single market on the Austrian insurance industry', Empirical Economics 28: 813-838.

Malmquist, S. (1953) 'Index Numbers and Indifference Surfaces', Trabajos de Estatistica 4: 209-242.

Noulas, A.G., Hatzigayios, T., Lazaridis, J. and Lyroudi, K. (2001) 'Non-parametric production frontier approach to the study of efficiency of non-life insurance companies in Greece', Journal of Financial Management and Analysis 14(1): 19-26.

Olson, M. (1965) The Logic of Collective Action: Public Goods and the Theory of Groups, Cambridge, MA: Harvard University Press.

Price, C.W. and Weyman-Jones, T. (1996) 'Malmquist indices of productivity change in the UK gas industry before and after privatization', Applied Economics 28: 29-39.

Raab, R. and Lichty, R.W. (2002) 'Identifying subareas that comprise a greater metropolitan area: the criterion of county relative efficiency', Journal of Regional Science 42(3): 579-594.

Rai, A. (1996) 'Cost Efficiency of International Insurance Firms', Journal of Financial Services Research 10: 213-233.

Simar, L. and Wilson, P.W. (1999) 'Estimating and bootstrapping Malmquist indices', European Journal of Operational Research 115: 459-471.

Simar, L. and Wilson, P.W. (2000) 'Statistical inference in nonparametric frontier models: The state of the art', Journal of Productivity Analysis 13: 49-78.

Seiford, L. and Thrall, R. (1990) 'Recent developments in DEA: The mathematical programming approach to frontier analysis', Journal of Econometrics 46: 7-38.

Thanassoulis, E. (2001) Introduction to the Theory and Application of Data Envelopment Analysis: A Foundation Text with Integrated Software, Dordrecht, NL: Kluwer Academic Publishers.

Varian, H.R. (1987) Intermediate Microeconomics: A Modern Approach, New York, W.W. Norton \& Co.

Williamson, O.E. (1998) 'The institutions of governance', American Economic Review 88(2): 75-79.

Williamson, O.E. (1994) 'Strategic economizing and economic organisations', in R.P. Rumelt, D.E. Schendel and D.J. Teece (eds) Fundamental Issues in Strategy, Boston, MA: Harvard Business School Press, pp. 361-402.

Zellner, A., Kmenta, J. and Dréze, J. (1966) 'Specification and estimation of Cobb-Douglas functions', Econometrica 34: 784-795.

\section{About the Authors}

Carlos Pestana Barros is auxiliary professor of Economics at ISEG-Instituto Superior de Economia e Gestão, Technical University of Lisbon with tenure. He holds a Ph.D. and M.S. in Economics, both from ISEG. His main research focus is on efficiency and 
productivity. His work has appeared in refereed journals such as Journal of Economic Studies, Journal of Socio-Economics, European Journal of Law and Economics, Annals of Public and Cooperative Economics, Journal of Conflict Resolution and Defence Economics.

Maria de Nazaré Esparteiro Barroso is auxiliary professor of Management at ISEGInstituto Superior de Economia e Gestão, Technical University of Lisbon. She holds a Ph.D. from Universidad de Navarra, Pamploon, Spain. Her main research focus is on risk and insurance.

Maria Rosa Borges is auxiliary professor of Economics at ISEG - Instituto Superior de Economia e Gestão, Technical University of Lisbon. She holds a Ph.D. and M.S. in Economics, both from ISEG. Her main research focus is on financial markets, efficiency and productivity. Her work has appeared in a refereed journal, Portuguese Journal of Management Studies and in Working Papers-series ISEG. 